\title{
Fungsi Implikatur Percakapan pada Tuturan Para Pelaku Talk Show Hotman Paris Show Unggahan Youtube 2020
}

\author{
Conversational Implicature Functions in the Speeches of the Talk Show Actors Hotman Paris \\ Show Youtube Upload 2020
}

\author{
${ }^{1)}$ Eko Suroso, ${ }^{2)}$ Siti Fathonah \\ ${ }^{1,2)}$ Universitas Muhammadiyah Purwokerto \\ *email: ekosuroso36@gmail.com
}

\begin{abstract}
Histori Artikel:
Diajukan:

$07 / 12 / 2021$

Diterima:

08/12/2021

Diterbitkan:

08/12/2021

Ketika peneliti melihat acara talk show Hotman Paris Show di youtube Januari 2020, peneliti menemukan tuturan Kamu diundang ke sini sebatas entertaiment kalau saya terima kado dari kamu, nanti saya seolah saya menghianati klien saya. Jadi kita hanya diskusi sebatas dunia akting tidak membahas kasus makanya pertama suara kamu kok bikin jangkrik bangun. Pada tuturan itu tampak adanya implikatur percakapan dengan fungsi menyatakan. Fungsi implikatur percakapan yang lain juga peneliti temukan pada beberapa percakapan yang berbeda. Permasalahan yang kemudian muncul adalah Fungsi Implikatur apa sajakah yang terdapat pada Para Pelaku Talk Show Hotman Paris Show Unggahan Youtube 2020? Impilikatur adalah penggunaan makna dibalik makna yang harfiah (makna non natural). Fungsi tuturan adalah Tuturan yang disampaikan penutur dengan maksud tersirat kepada mitra tutur. Fungsi tuturan itu ada tiga yaitu menyatatakan, menanyakan, dan menyuruh. Penelitian ini dilaksanakan dengan pendekatan deskriptif kualitatif. Data penelitian ini adalah tuturan Para Pelaku Talk Show Hotman Paris Show. Teknik pengambilan data dilakukan dengan teknik simak bebas libat cakap. Analisis data dilakukan dengan teknik padan pragmatik. Hasil penelitian menunjukkan bahwa tuturan para pelaku pada Talk Show Hotman Paris Show memiliki tiga fungsi implikatur percakapan yaitu fungsi menyatakan (Terbanyak), menanyakan (Cukup banyak), dan memerintah (sedikit).
\end{abstract}

\section{ABSTRAK}

Kata kunci: Tuturan, Fungsi, dan Implikatur

\begin{abstract}
When the researcher saw the Hotman Paris Show talk show on youtube in January 2020, the researcher found that your statement was invited here only for entertainment. If I receive a gift from you, it will be as if I betrayed my client. So we are only discussing the world of acting, not discussing cases, that's why first your voice makes the crickets wake up. In the speech, it appears that there are conversational implicatures with the function of stating. The researchers also found other conversational implicature functions in several different conversations. The problem that then arises is what are the implicature functions found in the Hotman Paris Show Talk Show Actors Uploaded by Youtube 2020? Implicature is the use of meaning behind the literal meaning (non-natural meaning). Speech function is speech conveyed by speakers with implied intentions to the speech partner. There are three functions of speech, namely stating, asking, and ordering. This research was conducted with a qualitative descriptive approach. The data of this research is the speech of the actors of the Hotman Paris Show Talk Show. The data collection technique was carried out using the free-to-talk technique. Data analysis was carried out using pragmatic matching technique. The results showed that the speech of the actors on the Talk Show Hotman Paris Show had three conversational implicature functions, namely the function of stating (mostly), asking (quite a lot), and commanding (slightly).
\end{abstract}


Eko Suroso, Siti Fathonah

Fungsi Implikatur Percakapan pada Tuturan Para Pelaku Talk Show Hotman Paris Show Unggahan

Youtube 2020

Keywords: Speech, Function, and Implicature

\section{PENDAHULUAN}

Ketika peneliti melihat acara talk show Hotman Paris Show di youtube Januari 2020, peneliti menemukan tuturan sebagai berikut:

(1.a) Hotman : Kamu diundang ke sini sebatas entertaiment kalau saya terima kado dari kamu, nanti saya seolah saya menghianati klien saya. Jadi kita hanya diskusi sebatas dunia akting tidak membahas kasus makanya pertama suara kamu kok bikin jangkrik bangun."

(1.b) Barbie : : Iya bagus banget internasional bang internasional itu lagunya aja langsung dicover di seluruh dunia.

Konteks : Hotman Paris adalah pembawa acara yang sekaligus juga pengacara klien bernama Fairus Arafiq yang berseteru dengan Galih Ginanjar suami dari Barbie Kumalasari. Hotman menolak pemberian kado dari Barbie agar tidak terjadi kesalapahaman antara pengacara dan kliennya (Fairus Arafiq)

Pada tuturan (1.a) tampak adanya implikatur percakapan dengan fungsi menyatakan. Hotman Paris menyatakan menolak pemberian hadiah oleh Barbie. Penyataan menolak Hotman Paris itu mengimpilkasikan bahwa Hotman Paris ingin menjaga profesionalismenya sebagai pengacara dan tidak ingin memunculkan kesan bahwa dirinya berkhianat pada kliennya. Oleh karena itu, pada tuturan 1a tersebut tampak adanya tuturan Hotman Paris yang menyatakan bahwa Barbie diundang ini sebatas sebagai entertaiment dan tidak membahas

kasus.
Implikatur percakapan fungsi menanyakan juga tampak pada acara yang sama dalam tuturan Hotman Paris sebagai berikut:

(2.a) Hotman : Viral karena gara-gara dianggap lu gak tau diri katanya soalnya gue posting lagu kamu tuh hampir 100 $\%$ semua marah-marah sakit kuping katanya?"

(2.b) Barbie : tapi buktinya kalau suaranya gak bagus, kenap abang posting." Konteks: Hotman memposting lagu Barbie dan mengomentari suara Barbie tidak bagus.

Walaupun dikenal tuturannya "ceplasceplos" dalam acara Hotman Paris Show, Hotman banyak mengungkapkan maksud secara tidak langsung (implisit) terutama untuk hal-hal yang bisa menyinggung perasaan narasumber. Seperti tuturan (2.a) diimplikasikan bahwa suara yang dimiliki oleh Barbie tidak bagus. Barbie dianggap viral karena percaya diri mengenai suara yang membuat orang lain marah terhadap Hotman. Tuturan (2.a) mengandung fungsi implikatur percakapan menanyakan dengan fungsi mempertanyakan yang kemudian disanggah dalam tuturan (2.b). Dalam tuturan (2.b) terdapat implikatur percakapan fungsi menanyakan yakni Barbie berusaha mempertanyakan ke Hotman jika suaranya tidak bagus maka lagu yang dinyanyikan mengapa diposting oleh Hotman.

Beberapa fenomena yang ditemukan tersebut memunculkan asumsi atau dugaan bahwa tuturan para pelaku talk show Hotman Paris Show banyak yang mengandung fungsi implikatur percakapan. Namun demikian, hal ini masih merupakan sebuah asumsi. Untuk mengetahui benar tidaknya asumsi itu, perlu dilakukan kajian secara empirik. Permaslahan yang kemudian muncul adalah Fungsi Implikatur Percakapan apakah yang terdapat pada Para Pelaku Talk Show Hotman Paris Show Unggahan Youtube 2020 ? 
Implikatur berasal dari kata implicatum (Austin, 1962). Istilah ini hampir sama dengan implication, yang artinya maksud, pengertian, keterlibatan. Menurut Grice (1957) konsep impikatur memecahkan persoalaan makna bahasa yang tidak dapat diselesaikan oleh teori semantik. Di antara penutur dan mitra tutur terdapat semacam kontrak percakapan tidak tertulis bahwa apa yang sedang dipertuturkan itu saling dimengerti sehingga disebut implikatur. Lebih lanjut, Grice membagi implikatur menjadi dua jenis yaitu; conventional implikatur (implikatur konvensional), dan conversation implikature (implikatur percakapan).

Fungsi menyatakan dalam implikatur percakapan memiliki beberapa ciri secara khusus. Ciri utama fungsi menyatakan adalah ketergantungannya pada konteks atau pengetahuan yang sama antara penutur dan mitra tutur (Wijana, 2013).. Tuturan yang memiliki makna tersirat sangat bergantung dengan konteks. Ciri selanjutnya adalah mitra tutur mengetahui, mengerti, memaklumi maksud penutur yang disampaikan oleh penutur secara tersirat. Petuturan dapat berupa pemberitahuan seperti infromasi, kejadian, atau peristiwa yang terjadi.

Fungsi menanyakan dalam Implikatur percakapan sangat bergantung pada konteks penafsiran antara penutur dan mitra tutur. Fungsi menanyakan sejalan dengan kalimat interogatif yang hasil jawaban, alasan, pendapat dari pembaca Lestari, E. P. (2019). Tuturan menyatakan bermodus kalimat interogatif adalah kalimat yang isinya mengharapkan reaksi atau jawaban berupa pengakuan keterangan, alasan, atau pendapat dari pihak pendengar atau pembaca.

Rohmadi, (2010). mengatakan bahwa tuturan dengan fungsi memerintah bermodus kalimat perintah (imperatif). Kalimat ini diujarkan oleh seorang penutur dengan harapan pendengar atau mitra tutur memberikan reaksi dalam bentuk tindakan secara fisik. Implikatur percakapan dengan fungsi memerintah dapat berupa tuturan yang mengandung kalimat imperatif. Tuturan yang demikian itu mengandung maksud memerintah atau meminta agar mitra tutur melakukan sesuatu sebagaimana dinginkan si penutur (Rahardi, 2005). Fungsi memerintah juga bisa diungkapkan dalam tuturan deklaratif dan tuturan interogatif (Rahardi, 2005).

Lazimnya, makna imperatif suruhan diungkapkan dengan tuturan imperatif. Penutur cenderung menggunakan tuturan nonimperatif untuk menyatakan tuturan imperatif. Penutur dapat menggunakan tuturan yang berkonstruksi deklaratif. Tuturan dengan konstruksi deklaratif banyak digunakan untuk menyatakan makna imperatif suruhan.

\section{METODE}

Pendekatan penelitian yang digunakan adalah penelitian deksriptif kualitatif. Data penelitian ini adalah tuturan para pelaku di Hotman Paris Show. Sumber data penelitian ini adalah para pelaku pada talk show hotman paris show yang di unggah Youtube 2020. Data penelitian ini dikumpulkan dengan teknik simak dasar dan teknik lanjutan. Teknik dasar yang dipilih adalah teknik sadap. Teknik sadap ini kemudian dilanjutkan dengan teknik lanjutan Simak Bebas Libat Cakap (SBLC) dan teknik catat. Analisis data pada penelitian ini menggunakan teknik padan pragmatik. Instrumen penelitian yang digunakan dalam penelitian ini adalah kriteria-kriteria penentu mengenai fungsi implikatur percakapan pada tuturan para pelaku dalam talk show Hotman Paris Show.

\section{HASIL DAN PEMBAHASAN}

\section{Fungsi Implikatur Percakapan Menyatakan pada Tuturan Peserta Tutur Talk Show Hotman Paris Show}

Ada beberapa ciri fungsi implikatur percakapan menyatakan pada tuturan para pelaku talk show Hotman Paris Show. Ciri pertama adalah tuturan itu diungkapkan melalui kalimat deklaratif. Ciri kedua adalah dikatakan secara implisit. Ciri ketiga adalah dipamahami secara implisit berdasarkan konteks atau pengetahuan bersama yang dimiliki. Ciri keempat adalah tuturan itu 
Eko Suroso, Siti Fathonah

Fungsi Implikatur Percakapan pada Tuturan Para Pelaku Talk Show Hotman Paris Show Unggahan

Youtube 2020

berupa pemberitahuan seperti informasi, kejadian, atau peristiwa yang terjadi. Fungsi implikatur percakapan menyatakan yang terdapat pada peserta tutur talk show Hotman Paris Show dapat dilihat sebagai berikut:

E.1. Hotman : Selamat para pemirsa ketemu lagi di Hotman Paris Show kali ini dengan asprinya sudah hampir cocok dengan topik kali ini Fakta atau settingan.

Cemburu aja luh.

E.2. Melani : "Ini lah para pemirsa nasib istri tua yang sehabis manis sepah dimut ya gak tapi gak papa biarin aja."

Konteks : Hotman membuka acara Hotman Paris Show berdampingan dengan asisten pembawa acaranya yang baru. Dari kejauhan juga ada Melani sebagai asisten pembawa acaranya yang lama.

Secara eksplisit tuturan pada E.2 menyatakan bahwa Melani adalah istri tua Hotman. Pada acara Hotman Paris Show terdapat dua asisten pembawa acara yang salah satunya adalah Melani. Secara implisit, Melani menyatakan bahwa dirinya adalah asisten pembawa acara di Hotman Paris Show yang sudah lama, tetapi Hotman lebih memilih asisten pembawa acaranya yang baru daripada Melani. Melani merasa dirinya telah dilupakan oleh Hotman. Pernyataan yang bersifat implisit yang dinyatakan oleh Melani merupakan implikatur percakapan menyatakan. Dengan pernyataan tersebut, Melani mengharapkan orang lain memahami bahwa dia asisten Hotman Paris yang lama. Melani menggunakan istilah istri tua dalam kenyataanya istri tua tentu lebih lama daripada istri baru, Dia juga menggunakan peribahasa sehabis manis sepah dimut yang berati Hotman Paris lebih memperdulikan asisten yang baru. Kalimat Melani juga dinyatakan sebagai kalimat deklaratif karena memenuhi ciri-ciri kalimat deklaratif yakni memiliki pola intonasi yang disebut pola intonasi berita.

Pada segmen yang sama peneliti juga menemukan implikatur percakapan

menyatakan pada data E.6. dalam talk show Hotman Paris Show, dapat dilihat sebagai berikut:

E6. Melani : Oh si abang main parkir sembarang perjamnya kena cash lo bang tapi yang pasti dunia artis gitu bang.

Demi ngetop demi popularitas ada yang sama-sama janjian, janjian metting makan siang settingan.

Begitubegitu diatur jembrengjembreng begitu ketemu seoah-olah ribut.

E7. Hotman : Bahkan ada yang ngaku bayar palah jadi artis yang lebih top bikin dengan 


$$
\begin{aligned}
& \text { bintang } \\
& \text { baru saya } \\
& \text { dengar } \\
& \text { tarifnya } 200 \\
& \text { juta ada } \\
& \text { yang pura- } \\
& \text { pura nikah } \\
& \text { tunangan } \\
& \text { pacaran, } \\
& \text { itulah ibu } \\
& \text { kota. }
\end{aligned}
$$

Konteks : Setiap malam rabu dan kamis pukul 21.00 WIB, talk show Hotman Paris Show selalu mengangkat masalah-masalah yang sedang hangat-hangat untuk dibahas. salah satunya adalah dunia artis yang settingan.

Melani pada data E.6 secara eksplisit melalui kalimat deklaratif-- menyatakan bahwa untuk bisa ngetop para artis perlu melakukan janjian makan siang settingan dan metting. Implikatur percakapan Melani dalam data E.6. berfungsi menyatakan bahwa para artis sekarang ini banyak memilih acara settingan daripada beneran. Yang dimaksud Settingan dalam hal itu adalah janjian dengan artis lain untuk merencanakan sensasi agar mereka terkenal. Fungsi Implikatur percakapan menyatakan juga terdapat pada tuturan mengetahui implikatur Melani seperti data E.7 sehingga Hotman juga menambahkan bahwa para artis juga rela membayar dan pura-pura menikah. Pernyataan yang bersifat implisit itu disebut implikatur percakapan menyatakan. Buktinya Hotman memahami pernyataan dari Melani. Topik yang sedang dibicarakan yaitu para artis rela melakukan apa saja demi popularitas diri, termasuk melakukan hal-hal yang bersifat pura-pura seperti pura-pura bertengkar, menikah, pacaran dan tunangan. Kalimat Melani, dinyatakan sebagai kalimat deklaratif karena memenuhi ciri-ciri kalimat deklaratif karena kalimat Melani merupakan informasi peristiwa artis saat ini.

Hal yang sama juga peneliti temukan pada data E.11. Pada data E.11 terdapat juga tuturan yang mengandung implikatur percakapan menyatakan. Tuturan selengkapnya adalah sebagai berikut:
E.10. Melani : Tapi ini kalau settingan atau fakta yang pasti berbicara mengenai tema malam ini cocok banget sama bintang tamu saat ini, dengerdenger katanya lagi skandal heboh dnegan youtuber terkenal.

E.11. Hotman : Selama ini menuduh saya ternyata saya lebih bersih dari semua lakilaki.

Konteks : Bintang tamu Hotman Paris Show adalah Liza, yang dikabarkan mempunyai skandal dengan yoTuber terkenal, youTuber terkenal ini sering dikaitkaitkan dengan berbagai wanita cantik.

Secara eksplisit kalimat yang terdapat pada data E.11 adalah kalimat deklaratif. Namun demikian, pada data E.11 tersebut terdapat implikatur percakapan menyatakan bahwa Hotman adalah laki-laki yang lebih bersih daripada semua laki-laki. Secara implisit Hotman menyatakan dirinya lebih baik dari laki-laki lain karena tidak memiliki banyak skandal dengan wanita lain. Pernyataan yang bersifat implisit itu disebut implikatur menyatakan. Buktinya, pernyataan implisit tersebut sesuai dengan topik perbincangan mengenai skandal YouTuber terkenal dengan wanita. Hotman mengharapkan orang lain memahami bahwa dirinya tidak memiliki masalah dengan 
wanita. Keadaan tersebut membuat Hotman merasa dirinya lebih baik daripada laki- laki lain.

Implikatur percakapan dengan fungsi menyatakan juga peneliti temukan pada data H.24.

Tuturan selengkapnya dapat dilihat sebagai berikut:

Hotman : Oke apa kata orang paling kaya sekarang di dunia ini Mark pendiri Facebook. Some people dream of succes while others wake up and work hard ai it berapa orang bermimpi untuk sukses ketika orang bangun subuh-subuh langsung kerja ya. Maksudnya mimpi aja gak cukup tapi bangunlah seperti Hotman bangun pagi jam 3 subuh ya. Salam Hotman Paris Show.

Melani : Terima kasih untuk Feby, Liza Gebe sukses terus kalian semua kita ketemu lagi di Hotman Paris Show.

Konteks : Sebelum acara berakhir Hotman memberikan Quetes mengenai salah satu pengalaman dirinya dalam menggapai kesuksesan.

Data H.24 secara eksplisit merupakan kalimat deklaratif. Hotman menyatakan bahwa untuk sukses, mimpi saja tidak cukup, tetapi harus bangun pagi jam 3, subuh. Fungsi implikatur percakapan Hotman tersebut adalah menyatakan. Dalam hal itu dinyatakan oleh Hotman bahwa untuk mengejar kesuksesan, bermimpi tidaklah cukup, maka berusahalah dengan kerja keras dan sungguhsungguh, rajin, tidak malas mulai dari hal-hal kecil, seperti bangun pagi. Seperti Hotman, yang sekarang menjadi orang sukses, pagi hari sudah mulai bekerja. Pernyataan yang besifat implisit itu merupakan implikatur percakapan menyatakan. Hal ini dibuktikan adanya Hotman yang mengharapkan orang lain memahami pesan dari dirinya. Secra implisit pula, pernyataan Hotman Paris tersebut juga menyatakan bahwa orang rajin dan suka bekerja keras biasanya suka bangun pagi. Kalimat Hotman juga dinyatakan sebagai kalimat deklaratif karena memenuhi ciri-ciri kalimat deklaratif dan memiliki pola intonasi berita. Pengalaman Hotman juga sebuah informasi yang menyatakan bahwa dirinya bangun subuh untuk mencapai kesuksesan.

Dalam percakapan S.22 dan S.23 terdapat pula fungsi implikatur percakapan menyatakan.

Percakapan selengkapnya adalah sebagai berikut:

Melani : Tepuk tangan dong. Terima kash buat Mba lal, Mas gunawan, kairu buat contoh para artis rumah tangga yang langgeng. Quetes bang.

Hotman : Quetes Hotman Paris Show malam ini adalah mengidolakan kemilau kesuksesan seperti berlian ya, lamborgini sepatu yang 55 juta ya. Tapi apakah kau pernah berpikir betapa air mata membahashi tumbuh tunas. Mulai karier dan ditaburi darah mengalir untuk mencapai karier tersebut ya. Jadi jangan hanya lihat kemilau kesuksesan berlian dan sebagainya. Oke salam Hotman Paris Show.

Konteks : Gunawan sebagai artis yang tetap bertahan, dan kerja keras Hotman sebagai pengacara membuat mereka terkenal dan sukses.

Kemilau kesuksesan seperti berlian, diraih dengan airmata membahasahi tunas dan mulai karier ditaburi darah mengalir untuk mencapai karier. Itu merupakan pernyataan Hotman sebgaimana terdapat pada data S.23. Secara eksplisit kalimat Hotman tersebut merupakan kalimat deklaratif. Namun demikian, secara implisit kalimat Hotman merupakan kalimat dengan fungsi implikatur 
percakapan menyatakan yaitu untuk mencapai kesuksesan karier dilalui dengan penderitaan dan kerja keras. Pernyataan yang bersifat implisit disebut fungsi implikatur percakapan menyatakan. Buktinya, Hotman mengharapkan penonton maupun bintang tamu memahami pernyataannya. Topik perbincangan berkaitan artis yang tetap bertahan dalam kesuksesan adanya upaya kerja keras dan pantang menyerah yang dilalui dengan penuh air mata seperti yang dilalui oleh Hotman dan Gunawan sebagai bintang tamu di acara Hotman Paris Show. Data (S.23) merupakan kalimat deklaratif karena isisnya memberikan sesuatu. Sesuatu itu berupa kejadian yang pernah dialami Hotman untuk mencapai kesuksesan.

\section{Fungsi Implikatur Percakapan Menanyakan pada Tuturan Peserta Tutur Talk Show Hotman Paris Show}

Fungsi Implikatur Percakapan

Menanyakan juga terdapat pada talk show Hotman Paris Show. Tuturan yang mengandung fungsi implikatur percakapan menanyakan yang dituturkan oleh peserta tutur talk show Hotman Paris Show. Fungsi implikatur percakapan menanyakan memiliki ciri sedikit berbeda dengan fungsi implikatur percakapan menyatakan yaitu, umumnya diungkapkan melalui kalimat deklaratif dan kalimat interogatif. Penutur menanyakan sesuatu kepada mitra tutur secara implisit, penafsirannya bergantung pada konteks. Penutur mengharapkan jawaban berupa penjelasan dari mitra tutur yang berisi informasi lengkap. Hasil jawaban berupa alasandan pendapat dari mitra tutur, --berdasarkan ciri yang ada-dijadikan indikator untuk menentukan fungsi implikatur percakapan menanyakan. Hasil tuturan dengan implikatur menanyakan yang ditemukan dalam talk show Hotman Paris Show dapat dilihat pada data A-2 berikut ini:

Melani

: Akhirnya para pemirsa
Hotman Paris Show tuh
bahagia banget loh. Aku
tuh happy loh kenapa
akhirnya abang akan
bertemu mantan pacarnya

kalau orang yang bertanya sebenarnya Hotman Paris selalu dikelilingi perempuan-perempuan cantik ya dan jenis cecan cewe cantik seperti apakah yang sebenarnya tipenya Hotman Paris banget maap ya bang maap banget biasanya abang kalau mendengar cecan akan abang semangat banget kok abang kedengarannya kayak keliataanya lemes what happen?

Hotman : Makanya buktikan dulu deh"(A.3)

Konteks : Pada awal sekmen, Hotman kedatangan tamu Barbie Kumasari. Hotman merupkan pengacara yang telah menangani kasus dari musuh Barbie. Hotman merasa tidak begitu senang akan kehadiran Barbie.

Pada data (A.2) secara eksplisit tampak adanya kalimat interogatif. Melani menanyakan, "mengapa Hotman terlihat lemes padahal akan bertemu dengan wanita cantik". Secara implisit Hotman dan Melani sebagai pembawa acara sudah mengetahui bintang tamu yang akan datang pastinya, Melani mengetahui mengapa Hotman tidak seperti biasanya bertemu dengan wanita cantik. Berbeda kali ini wanita cantik yang menjadi bintang tamu adalah Barbie, sehingga maksud implisit pertanyaan Melani adalah megapa Hotman tidak menyukai Barbie datang. Pertanyaan yang bersifat implisit yang dituturkan oleh Melani disebut impliaktur menanyakan. Buktinya, Hotman memahami dan memberikan jawaban seperti data (A.3). Data (A.2) adalah kalimat interogatif karena memiliki ciri-ciri kalimat interogatif yaitu intonasi naik pada akhir kalimat. Ciri kalimat interogatif sebagai salah satu acuan untuk membuktikan implikatur menanyakan, tetapi hal yang penting adalah maksud implisit pertanyaan Melani.

Data (B.6) juga mengandung fungsi implikatur percakapan menanyakan. Tuturasebagai 
Eko Suroso, Siti Fathonah

Fungsi Implikatur Percakapan pada Tuturan Para Pelaku Talk Show Hotman Paris Show Unggahan

Youtube 2020

berikut:

Hotman

arbie

\section{: Coba ini ini berarti kau sudah di permak semua dong dan gak ada yang asli dong?}

: Gak ini waktu udah mulai kurus, hidungnya sudah mulai kelhatan kalaui kita gemuk kan hidungnya ketutupan.

Konteks : Hotman paris kedatangan tamu Barbie

Kumalasari. Barbie Kumalsari dahulu memiliki tubuh yang gendut, tetapi saat ini Barbie sudah bertranformasi menjadi kurus.

Percakapan Hotmant pada data B.6 dan B.7 secara eksplisit menanyakan apakah Barbie sudah dipermak sehingga sudah tidak ada yang asli. Secara impslisit Hotman, menanyakan perubahan bentuk tubuh Barbie apakah melakukan operasi sehingga sekarang ini menjadi langsing tidak seperti dulu. Pertanyaan yang bersifat implisit itu merupakan implikatur menanyakan. Buktinya, Hotman mengharapkan jawaban dari Barbie berupa alasan mengenai perubahan tubuhnya bahwa dirinya tidak dioperasi. Data B.6 dinyatakan sebagai kalimat interogatif karena memenuhi ciri-ciri kalimat interogatif yaitu pola intonasi naik pada akhir kalimat. Ciri dari kalimat interogatif sebagai salah satu acuan untuk membuktikan adanya fungsi impliaktur percakapan menanyakan.

Fungsi Implikatur percakapan menanyakan juga peneliti juga temukan pada data percakapan B.22 dan B.23. Percekapan selengkapnya dapat dilihat sebagai berikut:

Melani : Jadi wajar dong kalau kemarin irmanya, irmanya kan di call me mel nih irma marah dia cerita katanya kan kalian berteman gitu terus irma kamu si ely katanya bertemen ya ada genggeng settingan ya namanya geng apasih. terus tiba- tiba dia lihat emang udah ijin atau mau coulab youtube kamu main adegan gendong- gendongan ya wajar dong kalau irma yang kesel gitu.

Barbie

: Ya kesel ya haknya dia ya kan namanya gendonggendongan itu kan cuma bercanda doang.

Konteks : Pada acara call me mell Irman becerita bahwa dia marah kepada Barbie. Diketahui Elly, Barbie, dan Irma memeiliki geng karena mereka sering kumpulkumpul. Petengkaran mereka juga disebut-sebut hanya settingan.

Kalimat Melani sebagaimana ada pada data B.22 secara eksplisit menunjukkan bahwa klaimat itu termasuk kalimat deklaratif. Melani menyatakan,bahwa Irma cerita dirinya marah kepada Barbie, sedangka Irma, Barbie dan Ely berteman punya geng yang namanya geng settingan. Secara implisit Melani menanyakan mengenai pertengakaran antara Barbie, Irma dan Ely hanya settingan karena diketahui bahwa mereka berteman. Pertanyaan yang bersifat implisit itu merupakan fungsi impliaktur percakapan menayakan dalam bentuk kalimat deklaratif. Dalam hal itu, Melani mengharapkan jawaban dari Barbie mengenai pertanyaanya tentang geng settingan. Data B.22 walaupun dinyatakan dengan kalimat deklaratif karena memenuhi ciri kalimat deklaratif (pola intonasi berita), namun data B.22 tersebut merupakan fungsi implikatur percakapan menanyakan.

Percakapan pada data B.36 dan B.37 merupakan percakapan dengan fungsi implikatur

menanyakan. Percakapan selengkapnya bisa dilihat pada percakapan sebagai berikut:

B.36. Melani : Namanya kan misteri games ya gak dikasih tau, kalau dikasih tahu namaya janjian udah settingan, jangan- 


\section{jangan udah settingan ya?}

B.37. Barbie : Gue aja kagak mau kalau ada dia.

Konteks : Barbie tidak suka

Irma juga diundang di acara

Hotman Paris Show pada

malam itu karena sebelumnya

mereka berdua sudah

bertengkar.

Fungsi implikatur percakapan sebagaimana pada data B.36 diungkapkan dalam bentuk kalimat interogatif secara eksplisit. Melani menanyakan Barbie dan Irma sudah janjian settingan. Secara implisit Melani menanyakan pertengkaran antara Barbie dan Irma sudah direncanakan agar membuat nama mereka sama-sama ngetop dan diundang di acara-acara. Pertanyaan Melani bersifat implisit yang disebut implikatur menanyakan. Buktinya adalah Barbie memberikan jawaban berupa penjelasan jika Irma datang dirinya tidak akan datang di acara tersebut. Data B.36 dinyatakan sebagai kalimat interogatif karena memiliki ciri-ciri kalimat interogatif yaitu intonasi naik pada akhir kalimat. Ciri kalimat interogatif merupakan salah satu acuan untuk membuktikan adanya fungsi implikatur percakapan menanyakan.

\section{Fungsi Implikatur Percakapan Memerintah pada Tuturan Peserta Tutur Talk Show Hotman Paris Show}

Dalam penelitian ini ditemukan berbagai tuturan dalam percakapan Hotman Paris Show dengan fungsi implikatur memerintah. Percakapan peserta tutur dalam talk show Hotman Paris Show --berdasarkan ciri-ciri implikatur memerintah-- memiliki empat ciri. Ciri-ciri yang dimaksud adalah tidak selalu kalimat perintah, dapat diungkapkan melalui kalimat deklaratif dan kalimat interogatif, mengharapkan mitra tutur melakukan tindakan yang diinginkan penutur bergantung konteks terjadinya percakpan, berupa tindakan secar a fisik maupun nonfisik, sehingga penutur mengharapkan mitra tutur untuk menjalankan apa yang dituturkan oleh penutur. Ciri tersebut jadikan indikator untuk menentukan tuturan implikatur memerintah pada peserta tutur talk show Hotman Paris Show. Hasil tuturan implikatur memerintah yang ditemukan dalam talk show Hotman Paris Show dapat dilihat sebagai berikut:

A.29. Hotman: Pengacara gue gak pernah lu bersidang di pengadilan.

A.30. Barbie : Kan gak harus bersidang ada anak buah bang.

A.31. Melani : Udah udah jangan ada tragedi kaya pas nikita atau nanti bintang tamu tersinggung mending gue cek asli.

A.32. Barbie : Asli emang abang aja yang punya.

Konteks: Hotman Paris yang sedang mengorek kehidupan Barbie, tentang penghasilannya untuk membeli berlian. Barbie menjelaskan bahwa dirinya juga pengacara, tetapi Hotman tidak percaya dan menyudutkan Barbie. Melani sebagai salah satu asisten pembawa acara menengahi agar tidak terjadi keributan seperti pada saat bintang tamunya Nikita.

Kalimat deklaratif yang terdapat pada data A.31 secara eksplisit Melani menyatakan bahwa jangan ada tragedi kaya pas Nikita nanti Bintang tamu tersinggung. Secara implisit Melani memerintahkan Hotman untuk tidak menyudutkan Barbie mengenai pekerjaan dan kehidupan Barbie. Melani takut jika Hotman terus-terusan menyudutkan Barbie akan terjadi keributan seperti Nikita. Jadi, Melani memberikan perintah kepada Hotman dalam bentuk kalimat deklaratif. Perintah dalam bentuk kalimat yang bersifat implisit merupakan implikatur memerintah. Buktinya, tidak selalu menggunakan kalimat perintah dapat berupa kalimat deklaratif. Melani 
mengharapkan adanya tindakan dari Barbie, tindakna tersebut berupa tindakan lisan yaitu berupa jawban pengalihan pembicaraan karena Barbie mengetahui apa yang dimaksudkan Melani.

Selain hal tersebut, terdapat pula fumgsi implikatur percakapan memerintah pada data

F.25. Percakapan selengkapnya bisa dilihat sebagai berikut.

Liza

Melani

Liza

Melani

\section{Konteks: Setelah Hotman mengorek kehidupan Liza Aditya tiba saatnya untuk talk show Hotman Paris Show iklan terlebih dahulu.}

Melani pada data F.25 secara ekplsit menyatakan melalui kalimat imperative bahwa jika Hotman belum puas maka akan mengorek Liza lebih dalam lagi.
Secara implisit Melani menyuruh
Hotman perbincangannya mengenai kehidupan Liza Aditya, karena akan ada jeda iklan. Perbincangan Hotman dan Liza bisa dilanjutkan setelah jeda iklan. Hotman memahami maksud implisit Melani. Hal ini dibuktikan Hotman tidak mengorek lagi kehidupan Liza pada sekmen itu, tetapi melanjutkan di sekmen berikutnya setelah iklan. Dengan demikian, permintaan Melano ini merupakan fungsi implikatur percakapan memerintah. Pada data

$$
\begin{array}{ll}
\text { M.1, juga } & \text { ditemukan } \\
\text { implikatur } & \text { percakapan } \\
\text { memerinta. } & \text { Percakapan }
\end{array}
$$

selengkapnya adalah sebagai berikut:

Melani

: Baik pemirsa kita kembali ke Hotman Paris Show sekmen terkahir masuk hakim bertanya terdakwa menjawab silakan!

Hotman : Hakim bertanya kepada Muzdalifah

pilihmeninggalkan apa ditinggalkan?

Konteks

: Melani membuka acara sekmen terakhir mem-persilakan Hotman untuk bertanya kepada para bintang tamu.

Kalimat imperatif sebagaimana yang terdapat pada data M.1, secara ekplisit menunujukkan bahwa Melani memerintah Hotman untuk bertanya kepada terdakwa. Secara implisit Melani mempersilakan Hotman untuk bertanya kepada Bintang tamu pada sekmen hakim bertanya terdakwa menjawab. Buktinya, Hotman memahami implikatur tuturan Melani karena itu, Hotman memulai pertanyaannya kepada bintang tamu. Kalimat pada data M.1 merupakan kalimat imperatif dengan penanda kata "silakan". Dengan demikian, persilaan yang berupa kalimat imperatif itu secara implisit merupakan fungsi implikatur percakapan memerintah. 
Eko Suroso, Siti Fathonah

Fungsi Implikatur Percakapan pada Tuturan Para Pelaku Talk Show Hotman Paris Show Unggahan

Youtube 2020

\section{KESIMPULAN}

\section{Simpulan}

Hasil penelitian ini dapat disimpulkan bahwa tedapat tuturan yang mengandung fungsi implikatur percakapan pada tuturan peserta tutur talk show Hotman Paris Show Unggahan YouTube Edisi November 2019. Implikatur percakapan terbagi menjadi tiga jenis yaitu implikatur menyatakan, implikatur menanyakan, dan implikatur memerintah. Fungsi implikatur percakapan menyatakan memiliki indikator yaitu diungkapkan melalui kalimat deklaratif, penutur menyampaikan atau mengatakan sesuatu kepada mitra tutur secara implisit, penfsirannya bergantung pada konteks percakapan, mitra tutur memahami pernyataan secara implisit berdasarkan konteks atau pengetahuan bersama yang dimiliki, tuturan dapat berupa pemberitahuan seperti informasi, kejadian, atau peristiwa yang terjadi. Fungsi implikatur percakapan menanyakan memiliki indikator yaitu umumnya diungkapkan melalui kalimat deklaratif dan kalimat interogatif, penutur menanyakan sesuatu kepada mitra tutur secara implisit, penafsirannya bergantung pada konteks, penutur mengharapkan jawaban berupa penjelasan dari mitra tutur yang berisi informasi lengkapa, hasil jawaban berupa alasan, pendapat dari mitra tutur. Fungsi implikatur percakapan memerintah memiliki indikator yaitu dapat diungkapkan melalui kalimat deklaratif dan kalimat interogatif, penutur mengharapkan mitra tutur melakukan tindakan yang diinginkan penutur bergantung konteks terjadinya percakpan, tindakan yang dilakukan oleh mitra tutur dapat berupa tindakan secar fisik maupun nonfisik, sehingga penutur mengharapkan mitra tutur untuk menjalankan apa yang dituturkan oleh penutur.

\section{Saran}

Kegiatan penelitian ini yang mengkaji tentang fungsi implikatur pada peserta tutur talk Show Hotman Paris Show, diharapkan ada pengkajian lanjutan sebagai pengembangan pengetahuan terhadap implikatur pada talk show lainnya. Bahasa bersifat dinamis tentu akan mempengaruhi segala sesutu yang berhubungan dengan bahasa salah satunya adalah talk show. Penelitian terhadap talk show akan menjadi bentuk penelitian yang menarik dimana ada infromasi yang terjadi pada sekarang ini. Peneliti melakukan penelitian ini, diharapkan menjadi bahan inspirasi bagi penelitian selanjutnya dalam melakukan penelitian talk show lainnya. Dari kegiatan penelitian yang telah dilakukaan perlu adanya tindak lanjut yang dapat memberikan wawasan dan pengetahuan pada pembaca, khususnya pembaca yang tertarik terhadapt bahasa mengenai fungsi implikatur pada talk show, karya sastra, dan sebagainya.

\section{DAFTAR PUSTAKA}

Abidin, Yunus. 2012. Pembelajaran Membaca Kamaruddin, S. (2012). Character Education and Students Social Behavior. Journal of Education and Learning (EduLearn), $6(4), \quad 223$. https://doi.org/10.11591/ edulearn. v6i4.166

Alwi, Hasan dkk. (2003). Tata Bahasa Baku Bahasa Indonesia. Jakarta: Pusat Bahasa dan Balai Pustaka.

Andrews, K. (2007). The Effects of Implicit and Explicit Instruction on Simple and Complex Grammatical Structures for Adult English Language Learners. Tesl-Ej, 11(2), $1-15$.

Anugerah Ash-shidiqqi, E. (2018). the Analysis of Character Education in Indonesia. International Journal of Humanities, Art and Social Studies (IJHAS), 3(4), 39-46.

Arikunto, Suharsimi. (2009). Manajemen Penelitian. Jakarta: Rineka Cipta.

Atlas, J. D. (2011). Logic, Meaning, and Conversation: Semantical Underdeterminacy, Implicature, and their Interface. In Logic, Meaning, and Conversation: Semantical Underdeterminacy, Implicature, and their Interface. https://doi.org/10.1093/ acprof:oso/ 9780195133004.001.0001 
Barnes, N. B. L. de J. A. L. (2009). Technology-Enhanced Learning. In Journal of Chemical Information and Modeling (Vol. 53). https://doi.org/10.1017/CBO978110 7415324.004

Brown, P. \&, \& Levinson, S. C. (1988). Politeness: Some Universals in Language Usage (Studies in Interactional Sociolinguistics 4). TESOL Quarterly, 22(4), 660. https://doi.org/

$10.2307 / 3587263$

Chaer, Abdul. (2010). Kesantunan Berbahasa. Jakarta: Rineka Cipta

Cooper, J., Press, P., \& Cooper, J. (1989). Principle of Personal Defence. Paladin Pres.

Dauti, A. (2017). Compensation for Immaterial (Moral) Damage Due To Violation of Personality Rights in Kosovo. Acta Universitatis Danubius. Juridica, 13(3), 104-120.

Degen, J., \& Tanenhaus, M. K. (2015). Processing scalar implicature A constraint-based approach.

Cognitive Science, 39(4), 667-710. https://doi.org/10.1111/cogs.12171 Grice, H. P. (1957). GRICE_PAUL_ MEANING (BOOKFI).pdf (pp. 377388). pp. 377-388.

Grice, H. P. (1975). Logic and conversation. Syntax and Semantics, 3: Speech Acts, eds Cole P, Morgan JL. New York: Academic Press, 3, 41-58. Retrieved from http://www.sfu.ca/ jeffpell/ Cogs300/GriceLogic Convers75.pdf

Habisch, A., \& Bachmann, C. (2016). Empowering practical wisdom from religious traditions: a ricoeurian approach. International Journal of Corporate Social Responsibility, 19. https://doi.org/10.1186/s40991016-0011-7

Handayani, L., Nugroho, S. E., Rohidi, T. R., \& Wiyanto. (2018). The use of Banyumas traditional art as analog sources of elementary school science materials. Journal of Physics: Conference Series, 983(1). https://doi.org/10.1088/17426596/983/1/012050

Igwedibia, A. (2017). Grice's Conversational Implicature: A Pragmatics Analysis of Selected Poems of Audre Lorde. International Journal of Applied Linguistics and English Literature, $7(1)$, 120. https://doi.org/10.7575/aiac.ijalel.v. 7n.1p. 120

Johnstone, C. L. (1996). Theory, Text, Context: Issues in Greek Rhetoric and Oratory SUNY Series in Speech Communication. In Notes. State University of New York Press, Albany.

Khan, Q., \& Bughio, F. A. (2012). Nunnery Scene: A pragmatic analysis of Hamlet-ophelia encounter. $3 L$ : Language, Linguistics, Literature, 18(2), 25-34.

Kurniasari, M. D., \& Mbato, C. L. (2018). Indonesian Students' Language Attitudes Towards Indonesian and English Through Education and Working Frame. Language and Language Teaching Journal, 21(Supplement), 69-86. https://doi.org/10.24071

/llt.2018.suppl2107

Leech, Geoffry N. (2011). Prinsip-Prinsip Pragmatik. Jakarta: Universitas Indonesia (UI-Press). Lestari, Elisa Puji. (2019). Implikatur Percakapan dalam Pementasan Drama Lautan Bernyanyi

Karya Putu Wijaya di Tayangan Youtube Unggahan Febuari 2019. Skripsi.Tidak Diterbitkan. Purwokerto: Universitas Muhammadiyah Purwokerto.

Levinson, S. C. (1983). Stephen C. Levinson Pragmatics.

Levinson, S. C. (1998). Presumptive Meanings: The Theory of Generalized Conversational Implicature Language, Speech, and Communication. In North.

Mahsun. (2005). Metode Penelitian Bahasa. Jakarta: Pt Raja Grafindo Persada. Mulyana. (2005). Kajian Wacana: 
Teori, Metode \& Prinsip-Prinsip Analisis Wacana. Yogyakarta: Tiara Wacana.

McKay, R., \& Whitehouse, H. (2015). Religion and morality. Psychological Bulletin, 141(2), $447-\quad 473$. https://doi.org/10.1037/a0038455

Mergler, A. (2008). Making the implicit explicit: Values and morals in Queensland teacher education. Australian Journal of Teacher Education, 33(4), 1-10. https://doi.org

/10.14221/ ajte.2008v33n4.1

Miller, J. H. (2005). Literature as conduct: Speech acts in Henry James. Literature as Conduct: Speech Acts in Henry James, 1-350. https://doi.org/10.1353/saf.2007.000 8

Moleong, Lexy J. (2004). Metodologi Penelitian Kualitatif. Bandung : PT Remaja Rosdakarya Offset.

Muzakki, K. (2018, May). Peredaran Narkoba di Kalangan Remaja di Banyumas Mengkhawatirkan Artikel ini telah tayang di Tribunjateng.com dengan judul Peredaran Narkoba di Kalangan Remaja di Banyumas Mengkhawatirkan,

https://jateng.tribunnews. com/2018/05/07/peredaran-narkobadi-kala. TRIBUNJATENG.COM, p. 1. Retrieved from https://jateng.tribunnews.com/2018/ 05/07/ peredaran-narkoba-dikalangan-remaja-di-banyumasmengkhawatirkan

Nadar, F. X. ( 2009). Pragmatik \& Penelitian Pragmatik. Yogyakarta: Graha Ilmu Putrayasa, Ida Bagus. (2014). Pragmatik. Yogyakarta: Graha Ilmu

Nanda, D. . (2015). IMPLICATURE IN JOHN GREEN 'S THE FAULT OF OUR STARS Dheril

Sofia Nanda State Islamic Senior High School 2 (MAN 2) of Kediri, Indonesia.

Jeels, 2(1), 44-61. Petrey, S. (2016). Speech acts and literary theory. Speech Acts and Literary Theory, Vol. 20, pp. 1175.

https://doi.org/10.4324/9781315537 436

Potts, Kennedy, C., Adger, D., \& Büring, D. (2005). The Logic of Conventional Implicatures A milestone in our understanding of the way that syntax and pragmatics interface with each other. Oxford: Oxford University Press.

Pulungan, M. Y. (2013). Pembelajaran Ranah Afektif Antara Harapan dan Kenyataan. Darul 'Ilmi, O1(02 Juli), 45-76.

Rahardi, Kunjana. (2005). Pragmatik Kesantuannan Imperatif Bahasa Indonesia. Jakarta: Erlangga.

Ramlan, M.(2001). Ilmu Bahasa Indonesia sintaksis. Yogyakarta:CV Karyono

Retnosari, H. (2018). PERGESERAN BAHASA JAWA DIALEK BANYUMASAN DI

KALANGAN REMAJA DALAM BERKOMUNIKASI. In Journal of Chemical Information and Modeling (Vol. 53). https://doi.org/10.1017/CBO978110 7415324.004

Ridlo Susanto, G. A. G. (2018, May). Marak, Pelajar Banyumas Pecandu Narkoba. G.A. Guritno, p.

1. Retrieved from https://www.gatra.com/detail/news/ 321120-Marak-Pelajar- BanyumasPecandu-Narkoba

Rido, A., Ibrahim, N., \& Nambiar, R. M. K. (2015). Interaction Strategies of Master Teachers in Indonesian Vocational Classroom: A Case Study. 21(3), 85-9

Rohmadi, Muhammad. (2010). Pragmatik teori dan Analisis. Surakarta: Yuma Pustaka Rokhman, F., Hum, M., Syaifudin, A., \& Yuliati. (2014). Character Education for Golden

Generation 2045 (National Character 
Building for Indonesian Golden Years). Procedia -Social and Behavioral Sciences, 141,1161$1165 . \quad$ https://doi.org/10.1016/ j.sbspro. 2014.05.197

Scott-Phillips, T. C. (2017). Pragmatics and the aims of language evolution. Psychonomic Bulletin and Review, 24(1), 186-189. https://doi.org/10.3758/s13423-0161061-2

Searle, J. R. (1979). Studies in the Theory of Speech Acts. In Philosophy. https:// doi.org/10.1213/01.ane.0000250225 $.96165 .4 \mathrm{~b}$

Setiadi, R., Kartadinata, S., Ilfiandra, \& Nakaya, A. (2017). A Peace Pedagogy Model for the Development of Peace Culture in An Education Setting. The Open Psychology Journal, 10(1), 182189.

https://doi.org/10.2174/1874350101 710010182

shandi@satelitpost.com. (2018, January). Januari, Ada 9 Kasus Persetubuhan Anak di Bawah Umur di Banyumas. Satelitpost.Com, p. 1. Retrieved from https://satelitpost.com/ beritautama/januari-ada-9-kasuspersetubuhan-anak-di-bawah-umurdi-banyumas

SHEPHERD, R. (1986). the Role of Attitudes and Beliefs in Food Choice. Appetite, 7(3), 233-234.

Spector, B., \& Sudo, Y. (2017). Presupposed ignorance and exhaustification: How scalar implicatures and presuppositions interact? In Linguistics and Philosophy. https://doi.org/10.1007/s10988-0179208-9

Stalnaker, R. (1999). Robert C. Stalnaker Context and Content- Essays on Intentionality in Speech and Thought (Oxford Cognitive Science Series)

Sudaryanto. (2015). Metode dan Aneka Teknik Analisis Bahasa. Yogyakarta: Sanata Dharma University Press.
Sugiyono. (2009). Metode Penelitian: Kualitatif, Kuantitatif, dan $R \& D$. Bandung: Alfabeta. Susanto, Edy. (2014). Sikap Masyarakat Surabaya terhadap talk Show "Hitam Putih" Tarigan, Henry Guntur (2009). Pengajaran Pragmatik. Bandung: Angkasa.

Tri Oktavianingrum. (2019). Implikatur Bermuatan Karakter dalam Wacana Pojok"Semarangan" Surat Kabar Suara Merdeka Edisi Desember 2018 dan Implikasinya bagi Pembelajaran Teks Eksposisi Kelas X SMA. Skripsi. Tidak Diterbitkan. Purwokerto: Universitas Muhammadiyah Purwokerto.

Wijana, I Dewa Putu. (1996). Dasar-dasar Pragmatik.Yogyakarta: Andi Offset Yule, George. (2006). Pragmatik. Yogyakarta: Pustaka Pelajar 